\title{
\#SchoolsOnFire
}

\section{Criminal justice responses to protests that impede the right to basic education}

\section{Ann Skelton and Martin Nsibirwa*}

ann.skelton@up.ac.za

mnsibirwa@gmail.com

http://dx.doi.org/10.17159/2413-3108/2017/i62a3090

In recent years, schools have borne the brunt of protesters' frustrations with the lack of access to services in South Africa. A 2016 investigative hearing by the South African Human Rights Commission (SAHRC) explored the causes of the protests and examined the failure to prevent the destruction of school property. It found that no one was held accountable for the protestrelated damage. This article explores the competing constitutionally protected rights of protest and education. Although the right to protest is central in a democracy, it must be exercised peacefully with minimal disruptions to the right to education. Protest action that causes destruction should be criminally sanctioned; however, action that impedes access to education through threats and intimidation is difficult to deal with in the criminal justice system. This article questions the applicability of section 3(6) of the South African Schools Act, which makes it an offence to stop children attending school, and considers the proposed amendments to the Act in light of these critiques. The article explores possible prosecution relying on the Intimidation Act, and finds that the Act is under constitutional challenge. The article concludes that the focus on prevention as contained in the SAHRC report is not misplaced, given the challenges in holding protesters accountable under criminal law.

In 2016 South Africa experienced a crisis of protest-related actions that affected tens of thousands of schoolgoing children, the majority of whom resided in Limpopo province. In the affected area of Vuwani, children were unable to attend school for several months. A total of 34 schools were badly damaged or

\footnotetext{
* Ann Skelton has a doctorate in law and is a professor at the University of Pretoria where she holds the UNESCO Chair in Education Law in Africa. Martin Nsibirwa holds a doctorate in law and is a senior manager at the South African Human Rights Commission. The views expressed in the article are his personal views.
}

destroyed through acts of arson, leaving 42000 children out of school. ${ }^{1}$ The root cause of this predicament was a long-standing municipal boundary demarcation dispute. ${ }^{2}$

The impact of protest-related actions was most severe in Vuwani. However, many other schools in Limpopo, even though not physically damaged, were unable to function due to threats against learners and educators. Besides impeding access to education, this protest action impacted school feeding programmes, which provide meals for many needy schoolgoing children. The estimated losses suffered 
by the education sector were assessed to be in the tens of millions of rands. ${ }^{3}$ Although the scale of the events in Vuwani was unprecedented, protest-related actions negatively affecting schools were not a new phenomenon. In 2014 similar events had taken place in Malamulele, in another area of Limpopo province.

The Vuwani crisis gave rise to a South African Human Rights Commission (SAHRC) national investigative hearing (2016 SAHRC hearing) into the impact of protest-related actions on the right to a basic education in South Africa. ${ }^{4}$ In addition to the problems in Limpopo province, the SAHRC had identified other incidents across the country that were also of concern. Threats to education were widespread across the country, with school principals, learners and educators often being intimidated when protest action was planned or underway.

According to the 2016 SAHRC hearing report, the large majority of protests impacting schools had nothing to do with the education sector and were instead related to border disputes and lack of basic services. ${ }^{5}$ Nevertheless, the interruption of schooling was considered fair game by protesters seeking immediate attention and faster resolution of their grievances.

The 2016 SAHRC hearing found that no individuals or groups had been held accountable for infringing the right to a basic education. However, the report did not delve into why protesters who contravened the criminal law through their protest-related actions were not held criminally liable. The report also did not examine what kinds of offences they might have been charged with, beyond considering in a cursory manner whether section 3 of the South African Schools Act (SASA), which makes it an offence to prevent a child from attending school, could be utilised in protest situations. ${ }^{6}$ This latter question is one to which this article returns below.
It is fairly clear that damage to property through arson or other destructive acts falls into the category of actions that must be dealt with under criminal law. However, other protest-related actions that do not result in physical damage but nevertheless impede or violate access to basic education are more difficult to categorise as actions warranting the attention of the criminal justice system. This article firstly considers why schools are being targeted for protest action. Secondly, in determining what the legal response to this should be, the article examines the legal underpinnings of the competing constitutionally protected rights that are brought into tension when protest action results in children being denied their right to basic education. Thirdly, the article asserts that acts of destruction or damage to property exceed the bounds of constitutionally protected protest and should result in prosecution. The article goes on to explore whether certain protest-related actions that impede access to basic education through threats and intimidation can and should be dealt with in the criminal justice system, and discusses the problems that are likely to be encountered. It concludes that these cases will be difficult to prosecute, and that the 2016 SAHRC investigative hearing's focus on prevention is therefore not entirely misplaced.

\section{Protests related to basic education in South Africa}

South Africa has an evocative history of protests related to education. The iconic image of the slain child, Hector Pieterson, being carried in the street during the 1976 Soweto uprising is etched on the national psyche. Following the establishment of a new order and the inclusion of the right to basic education in section 29(1)(a) of the South African Constitution, ${ }^{7}$ there was a period in which citizens waited patiently for their socio-economic rights to be delivered. However, after more than 10 years of the new order, service delivery protests began to erupt. 
Higher education was at the centre of the protests that erupted on South African university campuses during 2015 and 2016. While these protests were largely peaceful, there were incidents of damage to and destruction of property, and classes were cancelled for lengthy periods of time. ${ }^{8}$ The protests did at times impede the right of access to education. Using the Twitter hashtag '\#FeesMustFall' as their slogan, these protests were directed at addressing the issue of accessing free higher education. ${ }^{9}$ While it is important to acknowledge the impact of these protests on access to higher education, further discussion is beyond the scope of this article, which focuses on basic education. These protests are mentioned here to make the point that they are different from the school-related protests examined in the 2016 SAHRC investigative hearing, because the higher education protests were, unlike the school protests, directly related to accessing higher education for free.

In contrast, the SAHRC found that the majority of protests that affected access to basic education were in actual fact unrelated to education. ${ }^{10}$ For example, the protests in Limpopo mentioned above were as a result of residents' disapproval of decisions related to municipal demarcation. ${ }^{11}$ Reasons for protests at schools in other provinces included service delivery protests relating to lack of access to water, or to demand tarred roads. There are a myriad reasons why there are so many protests every year in South Africa; however, 'poverty', 'structural inequality', and 'inadequate access to basic services' have been identified as the underlying causes of such protest actions. ${ }^{12}$ This leads to the question why schools are so often the site of protests that have nothing to do with basic education.

The 2016 SAHRC hearing report found that 'some protest actions deliberately target schools with the intention of drawing attention to a cause that may be unrelated to basic education'. ${ }^{13}$ Actions that cause disruption of schools appear to be the fastest route to obtain a high-level government response. Public reaction to burning or damaging schools is one of incredulity. To some it is inconceivable why communities cut their own children off from education. The 2016 SAHRC hearing report shed some light on this phenomenon of communities burning or damaging their schools. The report noted that '[s]chools are seen as state property rather than an integral part of the community. The absence of a sense of ownership of schools by the communities in which they are situated makes it easy for schools to become a target'. ${ }^{14}$ The 2016 SAHRC hearing report also noted that 'disregard for the right to a basic education may also be based on a view that education is not necessarily a guarantee of a better life'. ${ }^{15}$

In 2017 there have been incidents of protests at schools that are, at least tangentially, linked to education issues. ${ }^{16}$ These protests have been initiated by parents or school governing bodies and are about the appointment of school principals who do not have the approval of some of the parents in the school. ${ }^{17}$ For example, in September 2017 the KwaZuluNatal High Court ordered police to intervene if parents continued to 'lock down' the premises of Assegai School. ${ }^{18}$

It is, in fact, rather surprising that parents have not protested about the state of basic education. The South African public education system is bifurcated, with better schools for the rich and worse schools for the poor. ${ }^{19}$ This is a country in which, in an effort to improve standards, non-governmental organisations have litigated on issues such as the existence of mud schools, ${ }^{20}$ admissions policies that favour wealthy schools, ${ }^{21}$ non-delivery of textbooks, ${ }^{22}$ failure to deliver school furniture, ${ }^{23}$ problems of scholar transport in rural areas, ${ }^{24}$ 
provision of teachers, ${ }^{25}$ and the policy of some schools to offer tuition only in the Afrikaans language. ${ }^{26}$ Yet these issues have not been the subject of protests on any significant scale.

It is an interesting question whether targeting schools to drive home frustrations about education would be more justifiable than targeting them for other service delivery failures. Such protests would be more rationally connected to their purpose, and would certainly be more understandable. A definitive answer to this question is beyond the scope of this article, which focuses instead on real-life situations where schools get burned, or children and educators are denied access to schools through threats and intimidation because of boundary demarcation or service delivery protests.

Whatever the reasons for schools being the target of protest action unrelated to education, the phenomenon is increasing. ${ }^{27}$ According to the South African Police Service (SAPS), South Africa experiences about 13500 protests every year. ${ }^{28}$ Something needs to be done to ensure that the disadvantages South African children are already experiencing in the basic education system are not compounded by their access to schools being impeded. Before considering the applicability of criminal sanctions, the legal basis of the competing rights will be examined in the next part of the article.

\section{Legal basis of the right to protest}

The right to protest is regarded as a major catalyst for much-needed social transformation in South Africa, particularly with respect to the poor and marginalised. ${ }^{29}$ Besides the constitutional guarantee of the right to protest, ${ }^{30}$ the right is further elaborated upon in the Regulation of Gatherings Act, addressing matters such as how to convene lawful gatherings, conduct protests, and procedures on provision of notices. ${ }^{31}$
In SATAWU and Another v Garvas and Others the Constitutional Court pronounced on the centrality and relevance of the right to safeguarding democracy in South African society, emphasising that: ${ }^{32}$

It exists primarily to give a voice to the powerless. This includes groups that do not have political or economic power, and other vulnerable persons. It provides an outlet for their frustrations. This right will, in many cases, be the only mechanism available to them to express their legitimate concerns. Indeed, it is one of the principal means by which ordinary people can meaningfully contribute to the constitutional objective of advancing human rights and freedoms.

The right to protest can be relied upon to advance other human rights. ${ }^{33}$ However, the right to protest, like all other rights, is not absolute and must be exercised with due regard to other rights. Organisers of protests should be mindful of "the risk of a violation of the rights of innocent bystanders which could result from forging ahead with the gathering'. ${ }^{34}$

The Constitutional Court noted that ordinary people may use the right to 'advance human rights and freedoms' and, furthermore, that it has 'foundational relevance to the exercise and achievement of all other rights'. At a fundamental level, therefore, the right to protest should ideally not undermine other rights but rather contribute to their realisation. The Constitutional Court has underscored that the cornerstone to the enjoyment of the right to protest is its peaceful exercise, and has indicated that 'it is important to emphasise that it is the holders of the right who must assemble and demonstrate peacefully. It is only when they have no intention of acting peacefully that they lose their constitutional protection.' ${ }^{35}$

The right is guaranteed in a number of international and regional human rights 
instruments to which South Africa is a state party. Among these are the Universal Declaration of Human Rights (UDHR), ${ }^{36}$ the International Covenant on Civil and Political Rights (ICCPR), ${ }^{37}$ and the African Charter on Human and Peoples' Rights (ACHPR). ${ }^{38}$

In international and regional human rights instruments the right to protest is recognised as a key component of democracy. ${ }^{39}$ Protest plays a crucial role in ensuring the realisation of economic, social, cultural, civil and political rights. ${ }^{40}$ Through protest, exchange of ideas becomes possible and unity of purpose in pursuit of common goals is promoted. ${ }^{41}$ The right to protest is thus central to social cohesion, especially in a society such as South Africa that has a fractured past. The state is under an obligation not to unreasonably curtail the right to protest.

\section{Basic education as a guaranteed right}

Education is central to the full development of the individual, and as such is a crucially important right. ${ }^{42}$ The right to education, particularly in the formative years of a person, is considered so critical that international and regional human rights treaties encourage states to ensure that it is free, compulsory and widely accessible. ${ }^{43}$ In General Comment 13 of the Committee on Economic, Social and Cultural Rights (CESCR), the importance of the right to basic education is explained as 'an empowerment right, education is the primary vehicle by which economically and socially marginalised adults and children can lift themselves out of poverty and obtain the means to participate fully in their communities.' ${ }^{44}$

The CESCR, in its General Comment 13, also requires states to protect the enjoyment of the right to education by ensuring that third parties do not interfere. States should also take 'positive measures to enable and assist individuals and communities to enjoy the right to a basic education'. ${ }^{45}$ This is an important international law impetus that holds that the state has a role to play in preventing and responding to interference with the right to education that occurs through protest.

General Comment 13 also provides guidance through the 4A framework: availability, accessibility, acceptability and adaptability. The right to protest, if exercised at schools or in preventing children from attending schools, interferes with the fulfilment of the 4A framework, particularly availability and accessibility. Where there is destruction or damage to schools, the impacts will be broader and will last longer.

The framing of section 29(1)(a) in the Constitution has clearly been influenced by international law, because it places emphasis on the right to basic education as an immediately realisable right. Education is a socio-economic right, and in the South African constitutional scheme such rights are generally progressively realisable. What this means in practice is that when it comes to rights such as housing or healthcare the government cannot be held to an unreasonable standard and be expected to realise these immediately. Progressive realisation requires the government to work consistently towards the fulfilment of rights for all persons, and it must not regress in its task. It must plan and budget in a reasonable manner. The clues in the Constitution to how socio-economic rights are to be delivered are provided in the phrases embedded in the relevant sections, such as 'to be progressively realised' and 'within available resources'.

It is of great significance, then, that section 29(1) (a), which embodies the right of basic education for all, does not contain such qualifying phrases. The subsection was interpreted in the case of Governing Body of the Juma Musjid Primary School and others $v$ Essay NO \& Others, ${ }^{46}$ where the Constitutional Court pointed out that '[u] nlike some of the other socio-economic rights, this right is immediately realisable. There is 
no internal limitation requiring that the right be "progressively realised" within "available resources" and subject to "reasonable legislative measures."' Van der Vyver is of the view that 'basic education is furthermore a fundamental right that must prevail over other conflicting constitutional rights and freedoms' ${ }^{47}$ This must be considered within a constitutional framework which the Constitutional Court has repeatedly stressed is non-hierarchical - in other words, no right is placed on a higher plane than others; all are treated alike. ${ }^{48}$ Nevertheless, when rights have to be balanced, one right may prevail over another; judged contextually.

The Constitutional Court also found, in the same case, that children's best interests must be considered where decisions will affect them. The case concerned a public school that was located on private property. The property owner had decided to sell the land and successfully sought a high court order for eviction of the school from the premises. The Constitutional Court found that the children's best interests should have been considered. Although the Constitutional Court ultimately allowed the eviction to go ahead, it only did so after requiring meaningful engagement between the parties, and when that failed, the court required a clear plan to be put in place to ensure that all affected learners were transferred to other suitable public schools.

The Constitution guarantees everyone the right to a basic education. ${ }^{49}$ While adult basic education is guaranteed, in reality children are the majority of recipients of basic education. The Constitution also includes, at section 28(2), the right to have children's best interests considered paramount in all matters that concern them. This brings into play an additional powerful constitutional protection in situations where children are prevented from attending school. ${ }^{50}$
Section 6(3) of SASA places an obligation on parents and guardians to ensure that children attend schools. ${ }^{51}$ It is an offence to interfere with children's attendance at school, although there are no known cases of prosecution for this offence. This section featured prominently in the 2016 SAHRC hearing report as a possible avenue to prosecute those preventing children from attending school. The avenues for the prosecution of offences committed in the context of protest are examined in the next part of this article.

\section{Criminal justice responses to protest action that impedes basic education}

The special recognition given to the right to basic education by the Constitution, and the fact that those affected by impediments to education are children, whose best interests must be considered in all matters affecting them, are factors that may tip the scales when weighing the competing rights at play. As mentioned above, the South African constitutional framework is one that values all rights as indivisible and does not envisage a hierarchy of rights. Each case where there are competing rights at play requires those rights to be weighed.

It is not argued here that the right to education, even when coupled with best interest considerations, should always trump the right to protest. Rather, it is submitted that the right to protest can be justifiably limited if it interferes with the right to education. In fact, the law already envisages this - because not all forms of protest are protected. It is only lawful, non-violent protest that enjoys constitutional protection.

In dealing with the question of whether protesters who obstruct the right to education should be prosecuted, South African authorities may want to draw inspiration from the European Court of Human Rights (ECHR), which has addressed the issue of the limits of protest, especially when obstruction or violence may ensue. 
According to the ECHR, peaceful assembly does not mean that no obstruction should occur during a demonstration. On the contrary, as a general rule, reasonable obstruction caused by assembly should in fact be protected by the law. ${ }^{52}$ However, the ECHR has also held the view that "physical conduct purposely obstructing traffic and the ordinary course of life in order to seriously disrupt the activities carried out by others is not at the core of that freedom'.53

According to the ECHR, protest action is only protected and guaranteed as long as it is peaceful. The moment the peaceful nature of protest ceases, the protesters can be subjected to prosecution. What would need to be demonstrated to avoid prosecution is that the protester at all times intended to and did remain peaceful. Those individuals who fail to adhere to peaceful intent and action, and who resort to obstruction of basic education would in principle open themselves to potential prosecution. ${ }^{54}$ During protest action, tolerance is expected from authorities as long as the activities are peaceful, and even when some level of damage is caused, authorities should still exercise restraint. ${ }^{55}$

Protest action that affects access to basic education in South Africa sometimes results in serious damage to property, far beyond what may be regarded as 'reasonable' damage that may have been anticipated by the ECHR in its interpretation of the right. In the South African context, damage to property that occurs as a result of violent protest should attract criminal prosecution, applying the common law offences such as malicious damage to property and arson.

Furthermore, protest action in South Africa, even when schools have not been damaged, may also attract liability if it is targeted at keeping schools closed or if it prevents scholars (or teachers) from attending school through threats or intimidation. This is particularly the case where children's access to education has been impacted for unreasonably long periods of time. Limiting the right to protest so that it does not undermine the right to education for extended periods would be a justifiable limitation, especially considering the principle of considering the best interests of the child.

The 2016 SAHRC hearing report recommends that section 3(6) of SASA, which makes it a crime to prevent children from attending school, be utilised as a basis for prosecution. ${ }^{56}$ The subsection states that parents who fail to ensure that their children attend school are guilty of an offence, and further, that any other person who, without just cause, prevents a learner from attending school, is guilty of an offence. In both cases, the person is liable on conviction to a fine or imprisonment not exceeding six months.

The 2016 SAHRC hearing report led to the Department of Basic Education's proposing an amendment to section 6(3) of SASA. The amendment clause appears in the Education Laws Amendment Bill issued for comment on 13 October 2017. ${ }^{57}$ Clause 2 of the Amendment Bill seeks to amend section 3(6) of SASA to increase the penalty provision from six months to six years in the case where the parent of a learner, or any other person, prevents a learner who is subject to compulsory school attendance from attending school. The Amendment Bill also creates a new statutory offence, which will be inserted as subsection 3(7), criminalising any person who wilfully interrupts or disrupts any school activity, or who wilfully hinders or obstructs any school in the performance of the school's activities, and sets a penalty clause of up to six months' imprisonment. The memorandum supporting the Amendment Bill explains that the amendment 'is necessitated by recent incidents, in several provinces, in which communities, or portions of communities, prevented learners from attending school in an attempt at making a political or other point'. ${ }^{58}$ 
It is clear, therefore, that the Department of Basic Education is intent on using this as the primary route for the prosecution of protest action that impedes education through threats and intimidation. Some complications are foreseen in taking this route. The original section was clearly aimed at parents who do not send their children to school owing to neglect, poverty, religious belief or other such reason. The section has not been used in the past, and some difficulties are anticipated in using it in the context of violent protest. It is apparent that parents should not be targeted for prosecution if their reason for not sending their children to school is the fear that they or their children may become victims of protest-related violence. It may be more appropriate to prosecute parents who are protesters themselves, who, it might be said, are 'using' interference with their children's schooling as a means to pressure authorities to accede to their demands. However, it may be difficult for the prosecution to prove motive and to distinguish between the different reasons why parents are keeping their children out of school - to protest, or to protect?

Prosecuting other persons, such as protest leaders who are not parents, under the clause that allows for 'any other person' who prevents a learner from attending school, may prove difficult in practice. The reason for this is that the parental responsibility to send children to school is an intervening factor. In other words, it may be difficult to prove that a call by a protest leader to 'stay away' from school was the cause for a child's non-attendance, when an intervening cause is the fact that the parents said, 'You had better stay at home today'. The legislation, even in its current form, is broadly worded to include 'any other person' who prevents children from attending school, but this was probably not intended to draw in third parties as remote as protesters. That is likely the reason why the Department of Basic Education, fuelled by the events of Vuwani and the findings of the 2016
SAHRC hearing report, has opted to broaden the scope of the section in a more express manner by adding the new statutory offence. ${ }^{59}$ The consequences of reading the section so widely is that it might draw other persons, such as striking teachers, into the cross hairs of possible prosecution, which is something to be considered before the amendment is made law. Increasing the penalties for such offences is an empty vessel - there is no penalty until there is a conviction, and for the reasons mentioned above, successful prosecutions appear to have relatively poor prospects. With regard to parents, the increase in penalty is objectionable, because to imprison caregivers is almost always going to run contrary to the best interests of the child, a fact which our Constitutional Court drove home firmly in the case of $S \vee M$ (Centre for Child Law as Amicus Curiae). ${ }^{60}$

Threats that prevent children (and teachers) from attending school should not be addressed solely through SASA. Direct threats, if identified, could be dealt with under the Intimidation Act. ${ }^{61}$ The Intimidation Act provides that any person who, without lawful reason and with intent to compel another person from doing an act or to take or abandon a particular standpoint in any manner and by so doing threatens to kill, assault or injure a person or people, will be guilty of an offence. ${ }^{62}$

The offence contemplated under the Intimidation Act includes acts, utterances or publications that have the effect (or could reasonably cause the effect) that the affected person (or any other person) fears for their life, personal safety and safety of property or livelihood. Persons convicted under the Intimidation Act are liable to a fine not exceeding R40 000 or to imprisonment not longer than 10 years, or to both such a fine and imprisonment. The Intimidation Act is controversial because it was enacted during the apartheid era and has not been repealed. Furthermore, it was the subject of a legal challenge in Moyo and Another v Minister of 
Justice and Correctional Services. ${ }^{63}$ Part of the challenge was that the definition of 'intimidation' was too broad and as such unconstitutional, on the basis that it effectively passes the onus to the accused to show that his or her acts had a lawful reason. In December 2016 the high court rejected the application and, at the time of writing, the matter is on appeal before the Supreme Court of Appeal.

Prosecution of protesters for the crime of intimidation may be justifiable, rational and proportionate where protest actions have resulted in children being kept out of school for long periods through threats or intimidation. However, there may be further hurdles in holding those responsible for such actions accountable under the criminal law. Firstly, it may be difficult to identify who should be charged with intimidation. Secondly, it may be difficult to prove that the threats actually amount to intimidation, especially as education does not amount to a 'livelihood' as required by the definition of intimidation, which falls short of threats to personal safety or property. The word 'livelihood' is a shorthand for protecting workers whose jobs may be threatened by protest or strike, but it does not expressly extend to school attendance. Finally, pursuing successful prosecutions, already difficult, may become more so if the constitutional challenge to the Intimidation Act is successful on appeal.

The 2016 SAHRC hearing found that '[m]any situations that escalate to the point where schools are targeted by protesters could be avoided'. The report recommends more prevention - in particular through engagement with communities that are expressing frustrations. Given the difficulties that may arise in prosecuting protesters who impede the right to education, government should heed this call to ensure prevention rather than waiting until during or after the protest. Furthermore, it is not only the Department of Basic Education that should be undertaking preventive action. Departments responsible for service delivery problems or demarcation disputes need to be more proactive and more communicative, and strive to engage meaningfully with communities to stave off protest. Engagement should also be targeted at building a sense of community ownership of public schools, which the 2016 SAHRC hearing report found to be lacking.

\section{Conclusion}

South Africa has a repressive history, which in itself is a good reason to be wary about restrictions of the right to protest. In the current environment of inequality, and the inadequacies in the delivery of services for the poor, it is clear that protest remains an important catalytic instrument for marginalised people. The Constitutional Court, while upholding the right and recognising its importance in giving a voice to the powerless and as a gateway to achieving other rights, has clearly stated that protest has to be exercised lawfully and must not negatively affect the rights of others.

The article has described protests that have affected schools in recent years. Although they are education-related in that they affect schooling, the article has shown that the vast majority of such protests are not about the right to education. Rather, schools are a site of struggle for other issues that communities are frustrated about, such as border demarcation and service delivery failures. The findings of the 2016 SAHRC hearing show that protesters are locating their battles in and around schools because schools are instrumentalised for the strategic advantage that such actions bring - namely swift, high-level attention from government. Protesters and even broader communities do not feel a sense of ownership over the public schools in their area, rather, they are seen merely as government property and therefore appear to be legitimate targets. 
The right to basic education is a crucially important right, which also provides a gateway to the fulfilment of other rights. The article argues that, coupled with the best interests of the child principle, the balancing of the right to protest on the one side and the right of children to attend school on the other means that the right to protest can be outweighed by the right to education where it impedes the latter, particularly over an extended period of time.

Although the authors acknowledge that the state should not be repressive in relation to protest action, it is quite clear that there are a number of protest-related actions that impact the right to education to a disproportionate degree. Acts of violence and arson that result in damage or destruction are criminal acts, which go beyond constitutional protection of the right to protest. The normal common law crimes clearly apply in such cases.

Far more difficult to bring within the criminal law ambit are threats that prevent children (and teachers) from attending school, sometimes for several months. The authors are of the view that the use of section 3(6) of SASA is a problematic avenue for criminal accountability, because it raises the concern that, ultimately, parents (who may or may not be involved in the protests) decide if their children should attend school - and where parents can raise a defence that their reason for not sending children to school was as a result of fear for their safety, criminal charges are unlikely to stick. The proposed amendments to SASA do not really provide answers to these problems of intention and causality. Although the amendments would expressly apply to third persons who interfere with the right to education, the causation problem remains because parents make the decision about whether to send their children to school. Increased penalties have no effect if there are few or no prosecutions, and when it comes to prosecuting parents, imprisonment of caregivers will simply raise another constitutionally untenable situation. The Intimidation Act, which at first glance appears to hold promise in responding to the problems, is in fact controversial and is, at the time of writing, under constitutional challenge.

Holding people who prevent children from realising their right to education through unlawful protest-related actions criminally liable is likely to remain difficult to achieve. The rumble of protest is a smoke signal indicating that trouble may be coming. To ensure that education is allowed to proceed unhindered, government should heed the 2016 SAHRC report's recommendations, and prevent unlawful protest through engagement at the earliest opportunity.

\section{To comment on this article visit \\ http://www.issafrica.org/sacq.php}

\section{Notes}

1 Media reports stated that the figure was 59000 affected learners, while the Limpopo Provincial Department of Education reported to the 2016 South African Human Rights Commission (SAHRC) hearing that 42000 learners were unable to attend school. See Poloko Tau, 60000 pupils affected as schools continue to be set alight in Vuwani, City Press, 6 May 2016, http://city-press.news24.com/ News/60-000-pupils-affected-as-schools-continue-to-beset-alight-in-vuwani-20160506 (accessed 28 October 2017); Greg Nicholson, Vuwani: after the ashes there is hope, Daily Maverick, 5 May 2017, https://www.dailymaverick.co.za/ article/2017-05-05-vuwani-after-the-ashes-theres-hope/\#. WfVXSVuCzX4 (accessed 28 October 2017); Kate Paterson and Tina Power (section 27), Report: A journey through the Vuwani schools' ashes, Daily Maverick, 11 May 2016, https:// www.dailymaverick.co.za/article/2016-05-11-report-rakingthrough-the-vuwani-schools-ashes/\#.WfVYhFuCzX4 (accessed 28 October 2017); Parliamentary Monitoring Group (PMG), Vuwani school destruction: update by Department of Basic Education, 24 May 2016, https://pmg.org.za/committeemeeting/22594/ (accessed 28 October 2017); Bekezela Phakathi, Pupils return to school in Vuwani as protests subside, Business Day, 31 August 2016, https://www. businesslive.co.za/bd/national/education/2016-08-31-pupilsreturn-to-school-in-vuwani-as-protests-subside/ (accessed 28 October 2017).

2 For a full explanation of the issues relating to municipal demarcation, see Southern African Legal Information Institute (SAFLII), Masia Traditional Authority and others v Municipal Demarcation Board and Others ZALMPPHC (29 April 2016), http://www.saflii.org/za/cases/ZALMPPHC/2016/1. html (accessed 29 August 2017). See also Lufuno Norman Makungo, Vuwani protest: Blaming the victim \& ignoring the causes, Ujuh, 11 May 2016, https://www.ujuh.co.za/ 
vuwani-protest-blaming-the-victims-ignoring-the-causes/ (accessed 28 October 2017); Piet Rampedi, Tribalism is the root cause of Vuwani and Malamulele uprisings and President Jacob Zuma fuelled it, writes Dr Thivhilaeli Simon Nedohe, African Times, 12 May 2016, https://www.africantimesnews. co.za/2016/05/12/tribalism-is-the-root-cause-of-vuwani-andmalamulele-uprisings-and-president-jacob-zuma-fuelled-itwrites-dr-thivhilaeli-simon-nedohe/ (accessed 28 October 2017).

3 Chantal Presence, Vuwani rebuild to cost 'hundreds of millions', iol, 10 May 2016, https://www.iol.co.za/news/crimecourts/vuwani-rebuild-to-cost-hundreds-of-millions-2019875 (accessed 24 September 2017).

4 The SAHRC is empowered to hold such meetings by sections 13 and 15 of the South African Human Rights Commission Act 2013 (Act 40 of 2013).

5 SAHRC, Report on national investigative hearing into the impact of protest-related action on the right to a basic education in South Africa, 37, https://www.sahrc.org.za/ home/21/files/WEBSITE\%20Impact\%20of\%20protest\%20 on\%20edu.pdf (accessed 29 August 2017).

6 South African Schools Act 1996 (Act 84 of 1996, SASA).

7 Constitution of the Republic of South Africa 1996 (Act 108 of 1996).

8 Kalisha Naicker, Students troubled as 'fees must fall' continues, News24, 4 October 2016, http://www.news24. com/SouthAfrica/Local/Hillcrest-Fever/students-troubled-asfees-must-fall-continues-20161003 (accessed 28 October 2017); Steven Tau and Rorisang Kgosana, Live report: Wits student protest turns violent, The Citizen, 11 October 2016, https://citizen.co.za/news/south-africa/1310641/live-reportmost-entrances-to-wits-reopened/ (accessed 28 October 2017); Jane Duncan, Opinion: Why student protests in SA have turned violent, Eyewitness News, 30 May 2016, http:// ewn.co.za/2016/09/30/OPINION-Why-student-protestsin-South-Africa-have-turned-violent (accessed 28 October 2017); Ashleigh Furlong, Thousands in fees must fall march on Parliament, GroundUp, 26 October 2016, https://www. groundup.org.za/article/fees-must-fall-almost-ends-withoutincident-violence-breaks-out/ (accessed 28 October 2017); Greg Nicholson, \#FeesMustFall: another day of violence as the state kicks issues forward, Daily Maverick, 12 October 2016, https://www.dailymaverick.co.za/article/2016-10-12feesmustfall-another-day-of-violence-as-the-state-kicksissues-forward/\#.WfVr-FuCzX4 (accessed 28 October 2017).

9 See Olwethu Mhaga, Universal education: 'a dream deferred'?, Pretoria Student Law Review, 2016, 10; Alan Straton, A short history of the \#FeesMustFall protest action, Mype News, 21 October 2015, http://mype.co.za/new/shorthistory-of-the-feesmustfall-protest-action-2/55011/2015/10 (accessed 28 October 2017).

10 SAHRC, Report on national investigative hearing, 37.

11 Masia Traditional Authority and others v Municipal Demarcation Board and others ZALMPPHC (29 April 2016).

12 SAHRC, Report on national investigative hearing, 4.

13 Ibid., 31.

14 lbid.

15 Ibid.

16 Regarding Klipspruit school, see T Makheta, School racism row: parents don't want a black principal, iol, 25 July 2017, https://www.iol.co.za/news/south-africa/gauteng/schoolracism-row-parents-dont-want-a-black-principal-10458915 (accessed 25 September 2017).

17 Regarding Vredendal North Primary School, see Shantel Moses, Slaps at school as parents battle new principal, Netwerk 24, 1 August 2017, http://www.news24.com/ SouthAfrica/News/slaps-at-school-as-parents-battle-newprincipal-20170801 (accessed 25 September 2017).

18 MEC for Basic Education, KwaZulu-Natal v School Governing Body of Assegai Primary School, KwaZulu-Natal High Court, Durban, 20 September 2017. See also Se-Anne Rall, Department of Education takes Assegai Primary parents to court, Daily News, 20 September 2017.

19 Nic Spaull, Education in SA: a tale of two systems, PoliticsWeb, 31 August 2012, http://www.politicsweb.co.za/ news-and-analysis/education-in-sa-a-tale-of-two-systems (accessed 24 September 2017).

20 Ann Skelton, Leveraging funds for school infrastructure: the South African Mud Schools Case Study, International Journal of Educational Development, 59, 2014.

21 MEC for Education in Gauteng Province and Others v Governing Body of Rivonia Primary School and Others 2013 (6) SA 582 (CC).

22 Section 27 v Minister of Education 2013 (3) SA 40 (GNP); Basic Education For All and Others v Minister of Basic Education and Others [2014] 3 All SA 56 (GP); Minister of Basic Education v Basic Education for All 2016 (4) SA 63 (SCA).

23 Madzodzo and Others v Minister of Basic Education and Others 2014 (3) SA 441 (ECM).

24 Tripartite Steering Committee and Another v Minister of Basic Education and Others (1830/2015) [2015] 3 All SA 718 (ECG).

25 The Centre for Child Law and Others v Minister of Basic Education and Others 2013 (3) SA 183 (ECG); Linkside and Others v Minister of Basic Education and Others (3844/2013) [2015] ZAECGHC.

26 Head of Department, Mpumalanga Department of Education $\checkmark$ Hoërskool Ermelo 2010 (2) SA 415 (CC); Centre for Child Law v Governing Body of Hoërskool Fochville [2016] 2 SA 121 (SCA).

$27 \mathrm{H}$ Kroukamp, Strategies to restore confidence in South African local government, African Journal of Public Affairs, 9, 2016. See also Kanelo Pitso, Our disillusioned youth know one thing: change is coming, Mail \& Guardian, 24 June 2016, https:// mg.co.za/article/2016-06-24-00-our-disillusioned-youth-knowone-thing-change-is-coming (accessed 28 October 2017).

28 Statistics presented by the SAPS at the SAHRC 2016 investigative hearing.

29 SAHRC, Report on national investigative hearing, 5.

301996 Constitution, section 17. See also ibid., para 3.

31 Regulation of Gatherings Act 1993 (Act 203 of 1993).

32 SATAWU and Another v Garvas and Others 2012 (ZACC) 13, 61.

33 Ibid.

34 Ibid., 68.

35 Ibid., 53.

36 Universal Declaration of Human Rights (UDHR), Articles 19 and 20. 
37 International Covenant on Civil and Political Rights, Articles 19(2), 21 and 22.

38 African Charter on Human and Peoples' Rights (ACHPR), Articles 9, 10 and 11.

39 Joint Report of Special Rapporteurs, Practical recommendations for the proper management of assemblies A/HRC/31/66, 2016 at [5]. See also Pierre de Vos, A problematic limitation on the right to freedom of assembly, Constitutionally Speaking blog, 6 October 2011, http:// constitutionallyspeaking.co.za/a-problematic-limitation-onthe-right-to-freedom-of-assembly/ (accessed 11 July 2016). De Vos notes with reference to South Africa that '[t]he right "peacefully and unarmed, to assemble, to demonstrate, to picket and to present petitions" was also enshrined in section 17 of South Africa's 1996 Constitution. This right is pivotal for the proper functioning of a democracy. If political organisations, civil society groups and members of the public are not free to demonstrate and to take part in protest marches, the participatory aspect of our democracy would be fatally weakened.'

40 Article 19, The right to protest: principles on protection of human rights in protest, Policy Brief, 2015, https://right-toprotest.org/wp-content/uploads/2015/06/right-to-protest-forweb.pdf (accessed 22 November 2017).

41 South African National Defence Union v Minister of Defence and Another (1997) ZACC 7, 8.

42 UDHR, Article 26(2).

43 Instruments that guarantee the right to a basic education in an effort to ensure full development of an individual include the UDHR, the ACHPR, the International Covenant on Economic, Social and Cultural Rights (ICESCR), the Convention on the Rights of the Child (CRC) and the African Charter on the Rights and Welfare of the Child (ACRWC).

44 Adopted at the $21^{\text {st }}$ session of the Committee on Economic, Social and Cultural Rights, 8 December 1999 (Contained in Document E/C.12/1999/10), para 1.

45 General Comment No 13, para 47.

46 Governing Body of the Juma Musjid Primary School and Others v Essay NO \& Others 2011(8) BCLR 761 (CC) para 37.

47 Ibid., para 30.

48 See, for example, De Reuck v Director of Public Prosecutions Witwatersrand Local Division) and Others (CCT5/03) [2003] ZACC 19; 2004 (1) SA 406 (CC), in which the Constitutional Court made it clear that although a child's best interests are of paramount consideration, this does not create a hierarchy of rights. It simply means that the right weighs heavily where rights are in tension with one another.

491996 Constitution, section 21(1)(a).

50 In S v M (Centre for Child Law as Amicus Curiae) 2008 (3) SA 232 (CC), while the Constitutional Court found that the paramountcy principle is not a trump, it nevertheless endorsed the best interests principle as a powerful consideration in the weighing of competing interests.

51 SASA, section 3.

52 See Karpyuk and Others v Ukraine ECHR judgment of 6 October 2015, para 207.

53 See Kudrevicius and Others v Lithuania ECHR judgment of 15 October 2015, para 93-98.

54 Ziliberberg v. Moldova ECHR decision of 4 May 2004, para 2.
55 Gün and others v Turkey ECHR judgment of 18 June 2013, para 74.

56 SAHRC, Report on national investigative hearing, 9.

57 Published in Government Gazette 41178/1101 on 13 October 2017.

58 Para 2,2 of the Memorandum published in the Government Gazette 41178/1101 on 13 October 2017.

59 Clause 2(b) of the Amendment Bill, which creates a new subsection 3(7) to be inserted into SASA.

60 S v M (Centre for Child Law as Amicus Curiae) 2008 (3) SA 232 (CC).

61 Intimidation Act 1982 (Act 72 of 1982).

62 Ibid.

63 Moyo and Another v Minister of Justice and Correctional Services 2017 (1) SACR 659 (GP) (20 Dec 2016). 